OPEN ACCESS

Edited by:

Suqing $\mathrm{Wu}$,

Wenzhou University, China

Reviewed by:

Fuzhen Liu,

Hubei University, China

Weilu Yang,

Jinan University, China

Shuaijun Wang,

Jiangsu University, China

*Correspondence:

Xiaohui Wang

wangxiaohui153.slyt@sinopec.com

Specialty section: This article was submitted to

Inorganic Chemistry,

a section of the journa

Frontiers in Chemistry

Received: 17 December 2021 Accepted: 20 December 2021

Published: 28 January 2022

Citation:

Wang $X$, Zhao J, Song C, Shi $X$ and Du $H$ (2022) An Eco-friendly Iron Cathode Electro-Fenton System Coupled With a pH-Regulation

Electrolysis Cell for $p$ -

nitrophenol Degradation.

Front. Chem. 9:837761.

doi: 10.3389/fchem.2021.837761

\section{An Eco-friendly Iron Cathode Electro-Fenton System Coupled With a pH-Regulation Electrolysis Cell for p-nitrophenol Degradation}

\author{
Xiaohui Wang ${ }^{1,2 *}$, Jingang Zhao ${ }^{1,2}$, Chunyan Song ${ }^{1,2}$, Xian Shi $^{1,2}$ and Haipeng $D u^{1,2}$ \\ ${ }^{1}$ Technical Test Center of Sinopec Shengli OilField, Dongying, China, ${ }^{2}$ Shengli Oilfield Testing and Evaluation Research Co., Ltd., \\ SINOPEC, Dongying, China
}

The high consumption of salt reagents and strict $\mathrm{pH}$ control are still bottlenecks for the full-scale application of the Fenton reaction. In this work, a novel eco-friendly iron cathode electrochemical Fenton (ICEF) system coupled with a $\mathrm{pH}$-regulation divided electrolysis cell was developed. In a $\mathrm{pH}$-regulation divided electrolysis system, the desired $\mathrm{pH}$ for an effective Fenton reaction and for a neutral treated media could be obtained by $\mathrm{H}_{2} \mathrm{O}$ splitting into $\mathrm{H}^{+}$and $\mathrm{OH}^{-}$at the anode and cathode, respectively. In an ICEF system, an iron plate was used as the cathode to inhibit the release of iron ions and promote the reduction of $\mathrm{Fe}^{3+}$ to $\mathrm{Fe}^{2+}$. It was found that when a potential of $1.2 \mathrm{~V} / \mathrm{SCE}$ was applied on the iron cathode, $98 \%$ of $p$-nitrophenol was removed in the combined system after $30 \mathrm{~min}$ with continuously adding $200 \mathrm{mg} / \mathrm{L}_{\text {of }} \mathrm{H}_{2} \mathrm{O}_{2}$. Meanwhile, a COD and TOC removal efficiency of 79 and $60 \%$ was obtained, respectively. In this case, the conductivity just slightly increased from 4.35 to $4.37 \mathrm{mS} / \mathrm{cm}$, minimizing the increase of water salinity, as compared with the conventional Fenton process. Generally, this combined system was eco-friendly, energy-efficient, and has the potential of being a promising technology for the removal of bio-refractory organic pollutants from wastewaters.

Keywords: pH-regulation, electrolysis, iron cathode, electro-fenton, salt

\section{INTRODUCTION}

Over the past few decades, advanced oxidation processes (AOPs) have attracted increasing interests for wastewater treatment since the highly oxidative hydroxyl radical $\left({ }^{\circ} \mathrm{OH}, \mathrm{E}^{0}=2.80 \mathrm{~V} / \mathrm{SHE}\right)$ was generated in situ and found to be capable of degrading any refractory organic molecules present in the aqueous solution until total mineralization at the kinetic constant values as high as $10^{8} \sim 10^{10} \mathrm{M}^{-1} \mathrm{~s}^{-1}$ (Andreozzi et al., 1999; Oturan and Aaron, 2014; Gao et al., 2018). Among various AOPs, the conventional Fenton reaction process has been most widely applied for the treatment of wastewater streams because it exhibits the advantages of fast reaction rates, mild operating conditions, and simplicity to control (Bello et al., 2019). The Fenton reaction mainly proceeds via two steps (Neyens and Baeyens, 2003; Moreira et al., 2017; Gao et al., 2020). The first stage is characterized by the rapid formation of $\bullet \mathrm{OH}$ from the homogeneous reaction between $\mathrm{Fe}^{2+}$ and $\mathrm{H}_{2} \mathrm{O}_{2}$ (Eq. 1), most of the pollutant degradation is achieved in this stage. The second stage is characterized by a slow reaction between $\mathrm{Fe}^{3+}$ and $\mathrm{H}_{2} \mathrm{O}_{2}$ for the regeneration of $\mathrm{Fe}^{2+}$ (Eq. 2), maintaining the continuous Fenton reaction (Babuponnusami and Muthukumar, 2014; Bello et al., 2019). 


$$
\mathrm{Fe}^{2+}+\mathrm{H}_{2} \mathrm{O}_{2} \rightarrow \mathrm{Fe}^{3+}+\mathrm{OH}^{-}+{ }^{\circ} \mathrm{OH} \mathrm{k}_{1}=63-76\left(\mathrm{~L} \mathrm{~mol}^{-1} \mathrm{~s}^{-1}\right)
$$

$\mathrm{Fe}^{3+}+\mathrm{H}_{2} \mathrm{O}_{2} \rightarrow \mathrm{Fe}^{2+}+{ }^{\bullet} \mathrm{HO}_{2}+\mathrm{H}^{+} \mathrm{k}_{2}=0.001-0.01\left(\mathrm{~L} \mathrm{~mol}^{-1} \mathrm{~s}^{-1}\right)$

However, the Fenton process has some drawbacks, which greatly hamper its industrial application (Babuponnusami and Muthukumar, 2014; Gao et al., 2020). The addition of concentrated acid reagent is indispensable to adjust the solution $\mathrm{pH}$ to $\sim 3.0$, that is the optimum condition for the Fenton reaction. However, working in such acidic $\mathrm{pH}$ requires the addition of a large amount of acid. In addition, massive alkaline reagents were also consumed for the subsequent neutralization of the treated solution. In addition, the employment of iron salt inevitably increases water salinity ( $\mathrm{Li}$ et al., 2013). The increased salt content probably makes this wastewater unacceptable for natural environments or poses significant pressure on the subsequent reverse osmosis unit (Wang et al., 2014; Fang et al., 2018). Besides, most of the Fenton reagents are added at once while over-dosage of either $\mathrm{H}_{2} \mathrm{O}_{2}$ or iron ions would lead to side reactions (Eq. 3 and Eq. 4). As a result, $\mathrm{Fe}^{3+}$ is massively accumulated from the oxidation of $\mathrm{Fe}^{2+}$ in the Fenton reaction system since $\mathrm{Fe}^{2+}$ regeneration from $\mathrm{Fe}^{3+}$ is very slow (Qiang et al., 2003). Thus, the reduction of $\mathrm{Fe}^{3+}$ to $\mathrm{Fe}^{2+}$ greatly limits the treatment performance of the Fenton reaction for pollutants degradation.

$$
\begin{aligned}
& \mathrm{Fe}^{2+}+{ }^{\bullet} \mathrm{OH} \rightarrow \mathrm{Fe}^{3+}+\mathrm{OH}^{-} \mathrm{k} 3=3.2 \times 10^{8}\left(\mathrm{~L} \mathrm{~mol}^{-1} \mathrm{~s}^{-1}\right) \\
& \cdot \mathrm{OH}+\mathrm{H}_{2} \mathrm{O}_{2} \rightarrow{ }^{\bullet} \mathrm{HO}_{2}+\mathrm{H}_{2} \mathrm{O} k_{4}=3.3 \times 10^{7}\left(\mathrm{~L} \mathrm{~mol}^{-1} \mathrm{~s}^{-1}\right)
\end{aligned}
$$

Over the recent decades, there has been growing interest in the research community to address the above limitations of the conventional Fenton process. The development of a heterogeneous Fenton system has been demonstrated to be a feasible strategy to avoid salt reagents addition, where iron oxides and other metal oxides such as goethite $(\alpha-\mathrm{FeOOH})$, magnetite $\left(\mathrm{Fe}_{3} \mathrm{O}_{4}\right)$, hematite $\left(\alpha-\mathrm{Fe}_{2} \mathrm{O}_{3}\right)$, and maghemite $(\gamma$ $\mathrm{Fe}_{2} \mathrm{O}_{3}$ ) have been commonly utilized as heterogeneous catalysts (Davarnejad and Azizi, 2016; He et al., 2016; Hassani et al., 2018; Görmez et al., 2019; Cai et al., 2021; Chen et al., 2021). Unlike the homogenous Fenton system, in a heterogeneous Fenton system, iron sources are immobilized within/on the catalyst structure, and the Fenton reaction occurs when the $\mathrm{H}_{2} \mathrm{O}_{2}$ molecule is in contact with the iron sites of the carrier, so that it is not necessary to continuously add the iron salts and $\mathrm{pH}$ limitation is reduced to some extent (Ganiyu et al., 2018; Cai et al., 2021; Hu et al., 2021). In spite of this, the most heterogeneous Fenton catalysts still operate optimally at $\mathrm{pH} 3-5$ and its catalytic performance is reduced in near-neutral water bodies because the catalyst turnover frequency is reduced by up to 100 -fold under neutral conditions (Cai et al., 2021; Chen et al., 2021).

Electro-Fenton is an emerging technology with well-known outstanding oxidation power, where the electron is utilized as the reagent to facilitate the regeneration of $\mathrm{Fe}^{2+}$ at the cathode (Eq. 5). Thus, this process exhibits higher performance in comparison with the conventional Fenton system because of the high utilization efficiency of $\mathrm{Fe}^{2+}$ (Oturan et al., 2000; Yuan et al., 2006; Brillas et al., 2009). Consequently, much more $\bullet \mathrm{OH}$ can be produced at a much smaller amount of iron salt addition. In fact, the addition of iron salts can be completely avoided with using a metal iron plate as the sacrificial anode material, where the electrochemically released $\mathrm{Fe}^{2+}$ can serve as the Fenton catalyst. In spite of this, the produced ferric sludge amount cannot be controlled effectively. Besides, concentrated acid and basic reagents are still required to regulate the solution $\mathrm{pH}$. In fact, in the typical electrolysis system, $\mathrm{OH}^{-}$and $\mathrm{H}^{+}$are produced at the cathode and anode, respectively, which can be separated well in the divided electrolysis cell. Inspired by this characteristic, the divided electrolysis cell can be used as the pH-regulation unit before and after the Fenton system to automatically acidify and neutralize the wastewaters without the requirement of chemicals. Besides, in the acid solution, the acidic dissolution of the metal iron plate can release the iron ions into the solution. Under the cathodic polarization of metal iron, the released iron ion amount can be well regulated. At the same time, $\mathrm{Fe}^{3+}$ can be also reduced to $\mathrm{Fe}^{2+}$ at the iron cathode. These collectively eliminate the limitations of the conventional Fenton process and promote its treatment efficiency for pollutants.

$$
\mathrm{Fe}^{3+}+\mathrm{e}^{-} \rightarrow \mathrm{Fe}^{2+}
$$

In this study, a novel electro-Fenton process coupled with a $\mathrm{pH}$-regulation divided electrolysis cell was developed for p-nitrophenol (PNP) degradation. In the $\mathrm{pH}$-regulation divided electrolysis cell with a PTFE membrane as the separated material, the desired $\mathrm{pH}$ for an effective Fenton reaction and for a neutral treated media could be obtained by $\mathrm{H}_{2} \mathrm{O}$ splitting into $\mathrm{H}^{+}$and $\mathrm{OH}^{-}$at the anode and cathode, respectively. In the electro-Fenton process with external addition of $\mathrm{H}_{2} \mathrm{O}_{2}$, metal iron and a DSA electrode were applied as the cathode and anode, respectively, where the cathodic polarization of the metal iron electrode could effectively reduce the release of iron ions with diminishing ferric sludge generation.

\section{EXPERIMENTAL SECTION}

\section{Materials}

An iron plate $(\mathrm{Fe},>99 \%)$ of $50 \times 50 \mathrm{~mm}$ was purchased from Tengfeng Metallic Material Co. Ltd. (Hebei, China). p-nitrophenol (PNP, $\mathrm{C}_{6} \mathrm{H}_{5} \mathrm{NO}_{3}, 99 \%$ ) was supplied from Shanghai Yien Chemical Technology Co. Ltd. 1,10phenanthroline $\left(\mathrm{C}_{12} \mathrm{H}_{8} \mathrm{~N}_{2} \cdot \mathrm{H}_{2} \mathrm{O}, 99 \%\right)$, glacial acetic acid $\left(\mathrm{C}_{2} \mathrm{H}_{4} \mathrm{O}_{2}, 99 \%\right)$, sodium acetate $\left(\mathrm{CH}_{3} \mathrm{COONa}, 99 \%\right)$, ferrous sulfate $\left(\mathrm{FeSO}_{4} .7 \mathrm{H}_{2} \mathrm{O}, 99 \%\right)$, hydroxylamine hydrochloride $\left(\mathrm{HONH}_{3} \mathrm{Cl}, 98.5 \%\right)$, sodium sulfate $\left(\mathrm{Na}_{2} \mathrm{SO}_{4}, 99 \%\right)$, hydrogen peroxide $\left(\mathrm{H}_{2} \mathrm{O}_{2}, 30 \%\right)$, titanium oxalate, potassium $\left(\mathrm{K}_{2} \mathrm{TiO}\left(\mathrm{C}_{2} \mathrm{O}_{4}\right)_{2}, 98 \%\right)$, ferrous ammonium sulfate hexahydrate $\left(\mathrm{Fe}\left(\mathrm{NH}_{4}\right)_{2} \cdot\left(\mathrm{SO}_{4}\right)_{2} \cdot 6 \mathrm{H}_{2} \mathrm{O}, 99 \%\right)$, potassium permanganate $\left(\mathrm{KMnO}_{4}, 99 \%\right)$, sulfuric acid $\left(\mathrm{H}_{2} \mathrm{SO}_{4}, 98 \%\right)$, and sodium 


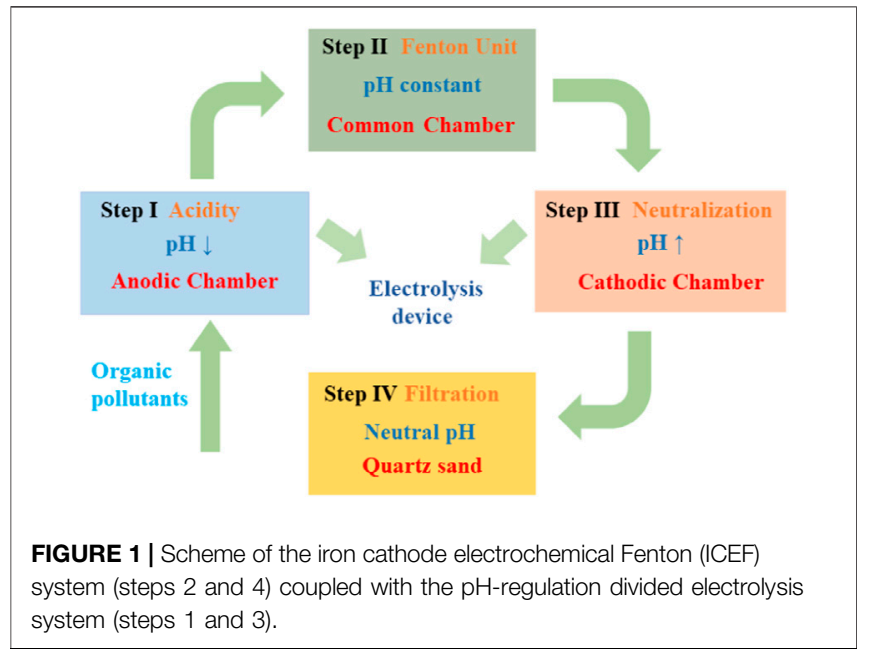

hydroxide $(\mathrm{NaOH}, 98 \%)$ were provided by Sinopharm Chemical Reagent Co. Ltd., China. All chemicals were analytical grade and were used without further purification. Ultrapure water $(18.2 \mathrm{M} \Omega \mathrm{cm})$ was used to prepare reaction solutions for all the experiments.

\section{Experimental Procedures}

As shown in Figure 1, the combined electrochemical treatment process mainly consisted of four steps. Prior to step 1, a $100 \mathrm{mg} / \mathrm{L}$ PNP solution with $\mathrm{pH} 7.0$ was performed in the beaker, $3 \mathrm{~g} / \mathrm{L}$ of $\mathrm{Na}_{2} \mathrm{SO}_{4}$ was used as the electrolyte solution. In step $1, \mathrm{pH}$ adjustment was carried out in the divided electrolysis cell, which used a plexiglass rectangular tank with the cathode and anode chambers isolated by a PTFE microfiltration membrane. The anode consisted of a $50 \times 80 \mathrm{~mm}$ boron-doped diamond (BDD) electrode while the cathode consisted of titanium mesh of the same dimensions with the distance of $25 \mathrm{~mm}$; the PTFE membrane was between the anode and cathode. The galvanostatic electrolysis reactions were performed by a DC power supply (voltage 0-30.0 V, electric current 0-5.0 A). In step 1, the PNP solution concurrently entered into the cathode and anode chambers, $\mathrm{pH}$ was reduced to near 3.0 in the anodic chamber within $1 \mathrm{~min}$. In step 2 , the solution with the reduced $\mathrm{pH}$ was added into the iron cathode electrochemical Fenton (ICEF) system for PNP degradation with a chamber volume of $500 \mathrm{ml}$ using a three-electrode potentiostat (Model CHI1130C, Chenhua instrument Co. Ltd. Shanghai, China) coupled with a saturated calomel reference electrode (SCE), where the cathodic potential was precisely controlled by the potentiostat and SCE. The working electrode was a $50 \times 50 \mathrm{~mm}$ iron plate, and the counter electrode was a $50 \times 50 \mathrm{~mm}$ DSA $\left(\mathrm{Ti}-\mathrm{RuO}_{2}-\mathrm{IrO}_{2}\right)$ mesh; $200 \mathrm{mg} / \mathrm{L}$ of $\mathrm{H}_{2} \mathrm{O}_{2}$ was continuously added by a pump within $15 \mathrm{~min}$. In step 3 , after the treatment of PNP solution in the ICEF system, the solution was transferred into the cathode chamber of the divided electrolysis cell to increase the $\mathrm{pH}$. In addition, the $\mathrm{pH}$ of the cathode effluent was further regulated to neutral $(\sim 9.0)$ by $\mathrm{NaOH}$ solution. In step 4 , the neutral solution was passed through a filter device to remove iron ions, which was carried out in a container filled with quartz sand $(80-120 \mathrm{~mm})$.
The removal ratio of p-nitrophenol, COD, or TOC $(\eta, \%)$ was calculated via Eq. 8.

$$
\eta=\frac{C_{0}-C_{t}}{C_{0}} \times 100 \%
$$

\section{Analytical Determinations}

The concentrations of PNP were determined by high performance liquid chromatography (HPLC-1100, Agilent) with an Eclipse XDB-C18 column $(4.6 \mathrm{~mm} \times 150 \mathrm{~mm}, 5 \mu \mathrm{m})$, (Nakatsuji et al., 2015). The mobile phase was methanol/water (50/50), the flow rate was $1.0 \mathrm{ml} / \mathrm{min}$, and the $\mathrm{UV}$ detector was set at $314 \mathrm{~nm}$. The chemical oxygen demand (COD) was detected using a COD analyzer (ASH 6B-80, China) [37]. A total organic carbon analyzer (multi $\mathrm{N} / \mathrm{C}^{\circledR} 2,100$, Analytik Jena $\mathrm{AG}$ ) was applied to monitor total organic carbon (TOC). (Kavitha and Palanivelu, 2004). The concentration of $\mathrm{H}_{2} \mathrm{O}_{2}$ was measured by the potassium titanium (IV) oxalate method at $400 \mathrm{~nm}$ with a UV-Vis spectrophotometer (UV 6000 PC Yuanxi instrument Co. Ltd. Shanghai, China) (Wang and $\mathrm{Chu}, 2011) . \mathrm{Fe}^{2+}$ and $\mathrm{Fe}$ (tot) were determined at $510 \mathrm{~nm}$ using a modified phenanthroline method with an $\mathrm{Fe}^{2+}$ detection limit of $0.5 \mu \mathrm{M}$, and $\mathrm{Fe}^{3+}$ concentration was estimated as the difference between $\mathrm{Fe}$ (tot) and $\mathrm{Fe}^{2+}$ (Xin et al., 2018). Solution $\mathrm{pH}$ and conductivity were measured by a water quality analyzer. The reaction was quenched in the collected samples by immediately adding $1.0 \mathrm{~mol} / \mathrm{L}$ of $\mathrm{NaOH}$ since Fenton oxidation cannot occur at $\mathrm{pH}>10.0$. For COD measurements, the samples were pretreated with $\mathrm{NaOH}$ to remove any residual $\mathrm{H}_{2} \mathrm{O}_{2}$. All experiments were performed twice at least, with relative errors less than $3 \%$.

\section{RESULTS AND DISCUSSION}

\section{pH-Regulation in a Divided Electrolysis Cell}

For the Fenton reaction, it is recommended to acidify the solution $\mathrm{pH}$ to $\sim 3.0$ for $\bullet \mathrm{OH}$ production and then neutralize the solution for the precipitation of $\mathrm{Fe}^{3+}$ (Chen et al., 2021). In this study, we developed a divided electrolysis cell using a hydrophilic PTFE microfilter membrane as the separated material. In this system, $\mathrm{H}_{2} \mathrm{O}$ splitting reactions at the anode and cathode could produce $\mathrm{H}^{+}$ and $\mathrm{OH}^{-}$(Eq. 7 and Eq. 8), respectively, which could be used to regulate the solution $\mathrm{pH}$ required for the Fenton reaction. Thus, the substrate solution $\mathrm{pH}$ could reduce to nearly 3.0 when it flowed through the anode chamber in step 1 (Figure 1). After the Fenton reaction, the solution $\mathrm{pH}$ was raised to promote the formation of $\mathrm{Fe}(\mathrm{OH})_{3}$ in step 3. The above $\mathrm{pH}$ adjustment objective could be achieved by regulating the applied current density and flow velocity. Here, a neutral solution containing $100 \mathrm{mg} / \mathrm{L}$ of PNP and $3 \mathrm{~g} / \mathrm{L}$ of $\mathrm{Na}_{2} \mathrm{SO}_{4}$ electrolyte was pumped into the electrolysis device at a flow rate of $20 \mathrm{ml} / \mathrm{min}$ by a peristaltic pump, where the residence time was $1 \mathrm{~min}$. The current density applied is the key parameter for the electrochemical $\mathrm{pH}$ regulation because it fundamentally affects the yield of $\mathrm{H}^{+}$in the anode compartment and $\mathrm{OH}^{-}$in the cathode compartment, respectively. As shown in Figure 2A, the $\mathrm{pH}$ of the anode effluent continuously decreased with the increase of current density; as the current density increased from 0.5 to $6 \mathrm{~mA} / \mathrm{cm}^{2}$, the 

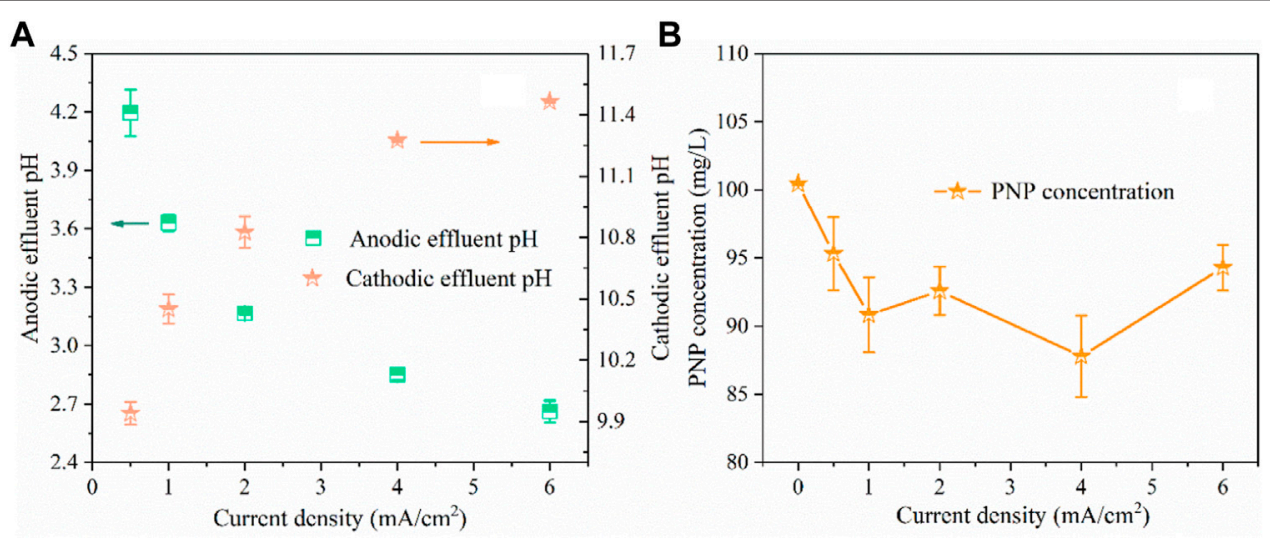

FIGURE 2 | The influence of current density on effluent $\mathrm{pH}(\mathbf{A})$ and $\mathrm{PNP}$ concentration (B). $\left(\mathrm{PNP}\right.$ concentration $=100 \mathrm{mg} / \mathrm{L}, \mathrm{Na}_{2} \mathrm{SO} \mathrm{H}_{4}=3 \mathrm{~g} / \mathrm{L}, \mathrm{pH} \mathrm{H}_{0}=7.0, \mathrm{anode}$ compartment flow velocity $=20 \mathrm{ml} / \mathrm{min}$, cathode compartment flow velocity $=20 \mathrm{ml} / \mathrm{min}$ ).

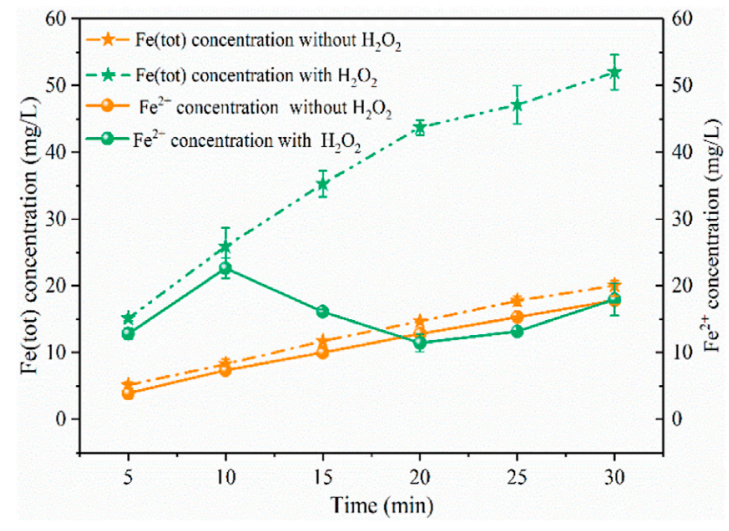

FIGURE 3 | Concentration variations of iron ions under different conditions. (PNP $=100 \mathrm{mg} / \mathrm{L}, \mathrm{Na}_{2} \mathrm{SO}_{4}=3 \mathrm{~g} / \mathrm{L}, \mathrm{pH}_{0}=3.0$ ).

$\mathrm{pH}$ of anodic effluent decreased from 4.2 to 2.7 , while the cathodic effluent $\mathrm{pH}$ increased from 9.9 to 11.5. This was consistent with what we expected, because as the current increased, effective watersplitting resulted in more $\mathrm{H}^{+}$produced at the anode and more $\mathrm{OH}^{-}$produced at the cathode. In particular, when the applied current density was $2 \mathrm{~mA} / \mathrm{cm}^{2}$, an acidic effluent with $\mathrm{pH}$ of 3-3.2 was automatically attained at the steady state (Neyens and Baeyens, 2003). It has been demonstrated that the Fenton process is inhibited at extremely acidic environments due to the formation of $\left(\mathrm{Fe}\left(\mathrm{H}_{2} \mathrm{O}\right)\right)^{2+}$ and $\mathrm{Fe}(\mathrm{III})$-hydroxyl complexes, $\mathrm{Fe}(\mathrm{OH})^{2+}$. Thus, to achieve the most favorable Fenton reaction condition, an applied current density of $2 \mathrm{~mA} / \mathrm{cm}^{2}$ was adopted in this study.

$$
\begin{array}{r}
2 \mathrm{H}_{2} \mathrm{O}+2 \mathrm{e}^{-} \rightarrow 2 \mathrm{OH}^{-}+\mathrm{H}_{2} \uparrow \\
2 \mathrm{H}_{2} \mathrm{O}-4 \mathrm{e}^{-} \rightarrow 4 \mathrm{H}^{+}+\mathrm{O}_{2} \uparrow
\end{array}
$$

The results in Figure 2B show that the PNP degradation efficiency increased as the current density increased initially from 0 to $1 \mathrm{~mA} / \mathrm{cm}^{2}$, but it became nearly constant when the current density was elevated above $1 \mathrm{~mA} / \mathrm{cm}^{2}$. Specifically, as the current density increased from 0.5 to $1 \mathrm{~mA} / \mathrm{cm}^{2}$, the PNP removal efficiency increased from 5 to $10 \%$. Nevertheless, further increasing the current density to $6 \mathrm{~mA} / \mathrm{cm}^{2}$ did not increase the further removal of PNP. In this case, the BDD anode had little effect on the degradation of pollutants in this system because of a too short residence time.

\section{Iron Plate Immersed in Water Without Electricity}

As shown in Figure 3, when the solution $\mathrm{pH}$ reduced to nearly 3.0 , the iron plate immersed in water without power could produce $20 \mathrm{mg} / \mathrm{L}$ of $\mathrm{Fe}$ (tot) within $30 \mathrm{~min}$, of which $89 \%$ was $\mathrm{Fe}(\mathrm{II})$. In this process, the iron plate would be dissolved by $\mathrm{H}^{+}$to generate $\mathrm{Fe}^{2+}$ under acidic conditions through Eq. 9, and the oxidation of $\mathrm{Fe}^{2+}$ to $\mathrm{Fe}^{3+}$ by $\mathrm{O}_{2}$ was slow and the solution $\mathrm{pH}$ increased slightly from 3.0 to 3.2 . The average production rate of $\mathrm{Fe}$ (tot) (approximately $0.33 \mathrm{mg} / \mathrm{min}$ ) and $\mathrm{Fe}^{2+}$ (approximately $0.3 \mathrm{mg} / \mathrm{min}$ ) was stable and closed within $30 \mathrm{~min}$, indicating the stable release of $\mathrm{Fe}^{2+}$ by the iron plate under the acid solution. Under the same conditions, Fe (tot) significantly increased to $52 \mathrm{mg} / \mathrm{L}$ after $200 \mathrm{mg} / \mathrm{L}$ of $\mathrm{H}_{2} \mathrm{O}_{2}$ was continuously added into the solution within $15 \mathrm{~min}$. The average production rate of $\mathrm{Fe}$ (tot) was stable within $20 \mathrm{~min}$ (approximately $1.1 \mathrm{mg} / \mathrm{min}$ ), which was three times higher than that without the addition of $\mathrm{H}_{2} \mathrm{O}_{2}$. But these two reactions exhibited a similar average production rate of Fe (tot), approximately $0.41 \mathrm{mg} / \mathrm{min}$, within the reaction period of 20-30 min, which may be ascribed to the fact that most of the $\mathrm{H}_{2} \mathrm{O}_{2}$ was consumed within $20 \mathrm{~min}$. As for $\mathrm{Fe}^{2+}$ concentration, it continuously increased within $10 \mathrm{~min}$ with the production rate of approximately $1.13 \mathrm{mg} / \mathrm{min}$ and decreased from 23 to $11 \mathrm{mg} / \mathrm{L}$ between 10 and $20 \mathrm{~min}$, which was explained by the consumption of $\mathrm{Fe}^{2+}$ during the Fenton reaction process (Eq. 1). And after $20 \mathrm{~min}$, the concentration continuously increased, finally reaching $18 \mathrm{mg} / \mathrm{L}$ at $30 \mathrm{~min}$, accounting for $35 \%$ of the $\mathrm{Fe}$ (tot). Within 20-30 min, the Fe (tot) concentration increased by $8 \mathrm{mg} / \mathrm{L}$, close to the value of $\mathrm{Fe}^{2+}$ increase $(7 \mathrm{mg} / \mathrm{L})$, this can also be explained by the fact that little $\mathrm{H}_{2} \mathrm{O}_{2}$ remained after 20 min and the increase of $\mathrm{Fe}$ (tot) concentration was mostly due 

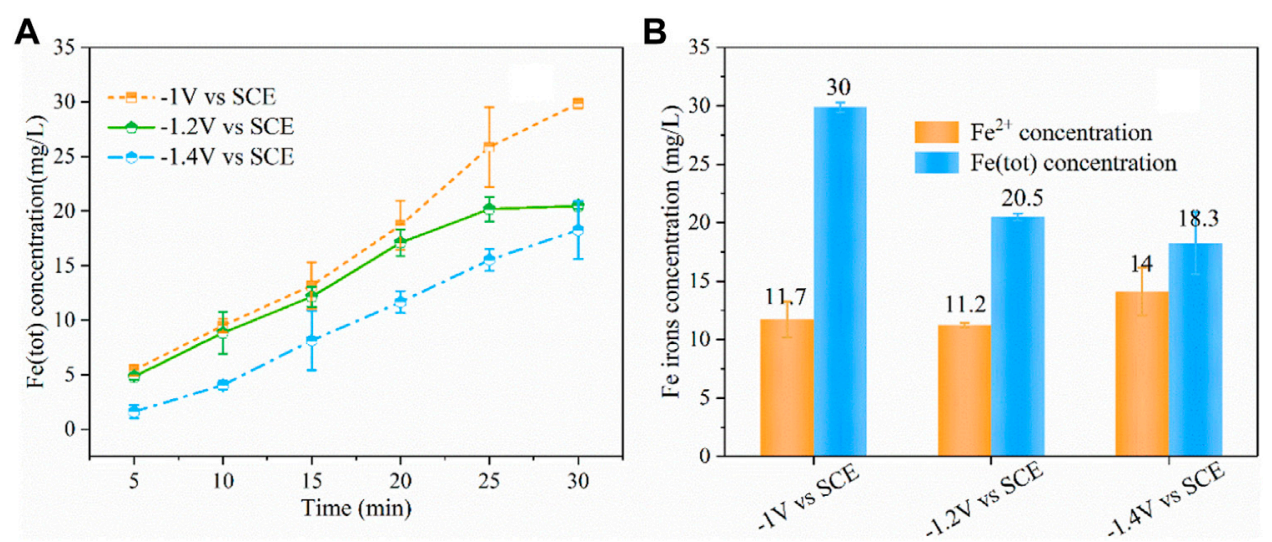

FIGURE 4 | Concentration variations of Fe (tot) under different cathodic potentials (A), concentration of Fe irons at 30 min under different cathodic potentials (B). (PNP $=100 \mathrm{mg} / \mathrm{L}, \mathrm{Na}_{2} \mathrm{SO}_{4}=3 \mathrm{~g} / \mathrm{L}, \mathrm{pH}_{0}=3.0$ ).

to the $\mathrm{Fe}^{2+}$ released (Eq. 9). The above results revealed that the presence of $\mathrm{H}_{2} \mathrm{O}_{2}$ could facilitate the release of iron ions from $\mathrm{Fe}^{0}$ in the acid solution. In this case, a large amount of iron sludge was produced and side reactions (Eq. 3) might consume produced $\bullet \mathrm{OH}$, leading to inferior degradation of pollutants.

$$
\mathrm{Fe}+2 \mathrm{H}^{+} \rightarrow \mathrm{Fe}^{2+}+\mathrm{H}_{2}
$$

\section{Effect of Different Potential Applied to Iron Plate Cathode in ICEF System}

To further reduce the release of iron ions from the iron cathode and improve the regeneration of $\mathrm{Fe}^{2+}$ from $\mathrm{Fe}^{3+}$, we developed a novel iron cathode electro-Fenton system, applying a potential on the iron cathode. Figure $\mathbf{4 A}$ shows that concentration variations of $\mathrm{Fe}$ (tot) under different cathodic potentials, it was found that as the applied cathodic potential increased, the produced $\mathrm{Fe}$ (tot) decreased continuously. At the cathodic potential of -1.0 and $-1.2 \mathrm{~V} / \mathrm{SCE}$, the produced $\mathrm{Fe}$ (tot) concentration was 30 and $21 \mathrm{mg} / \mathrm{L}$ within $30 \mathrm{~min}$, which reduced by 42 and $61 \%$, respectively, compared with no electricity input. Further increasing the cathodic potential from -1.2 to $-1.4 \mathrm{~V} / \mathrm{SCE}$ resulted in the slight decrease of $\mathrm{Fe}$ (tot) concentration to $18 \mathrm{mg} / \mathrm{L}$. The production rate of $\mathrm{Fe}$ (tot) $(0.43 \mathrm{mg} / \mathrm{min})$ at the cathodic potential of $-1.2 \mathrm{~V} / \mathrm{SCE}$ was significantly higher than $-1.4 \mathrm{~V} / \mathrm{SCE}(0.29 \mathrm{mg} / \mathrm{min})$ within the initial $20 \mathrm{~min}$, while the value was apparently decreased to $0.17 \mathrm{mg} / \mathrm{min}$ within $20-30 \mathrm{~min}$, and the rate slightly increased to $0.33 \mathrm{mg} / \mathrm{min}$ during the same time at $-1.4 \mathrm{~V} /$ SCE. Figure 4B shows the $\mathrm{Fe}^{2+}$ and $\mathrm{Fe}$ (tot) concentrations produced at $30 \mathrm{~min}$ under different cathodic potentials. It was found that the ratio of $\mathrm{Fe}^{2+}$ to $\mathrm{Fe}$ (tot) concentration enhanced significantly from 0.39 to 0.77 with the decrease of cathodic potential from -1.0 to $-1.4 \mathrm{~V} / \mathrm{SCE}$. This can be explained by the fact that the regeneration from $\mathrm{Fe}^{3+}$ to $\mathrm{Fe}^{2+}$ increased with the decrease of cathodic potential.

The results of PNP concentration versus time are shown in Figure 5A. It was found that only $75 \%$ of PNP was degraded within 30 min under the conditions of the iron plate immersed in water with $200 \mathrm{mg} / \mathrm{L}$ of $\mathrm{H}_{2} \mathrm{O}_{2}$ without electricity (WE Fenton process). And PNP removal efficiency was enhanced to 87,91 , and $90 \%$ at cathodic potentials of $-1.0,-1.2$, and $-1.4 \mathrm{~V} / \mathrm{SCE}$, respectively (Kavitha and Palanivelu, 2004). However, it is noted that the removal efficiency was inferior initially then reached similar levels as the others after $20 \mathrm{~min}$ at $-1.4 \mathrm{~V} / \mathrm{SCE}$. In addition, COD removal efficiency was basically the same in the case of -1 and $-1.2 \mathrm{~V} / \mathrm{SCE}$, whereas the treatment at $-1.4 \mathrm{~V} / \mathrm{SCE}$ exhibited an inferior degradation rate. As shown in Figure 5B, the COD removal efficiency was $67 \%$ without electricity, and increased to 76 and $75 \%$ at the cathodic potentials of -1.0 and $-1.2 \mathrm{~V} / \mathrm{SCE}$, respectively, with residual COD concentration below $50 \mathrm{mg} / \mathrm{L}$. However, when the cathodic potential was decreased to $-1.4 \mathrm{~V} / \mathrm{SCE}$, the COD concentration reduced from 154 to $73 \mathrm{mg} / \mathrm{L}$ within $30 \mathrm{~min}$, which can be ascribed to the inferior production of Fe (tot) for the Fenton reaction. According to the above results, $-1.2 \mathrm{~V} /$ SCE was chosen as the optimal cathodic potential, and the released $\mathrm{Fe}$ (tot) concentration decreased by approximately $61 \%$ with the COD concentration further decreasing from 52 to $40 \mathrm{mg} / \mathrm{L}$ as compared with the WE Fenton process. The degradation of the $100 \mathrm{mg} / \mathrm{L}$ PNP solution was carried out in the traditional Fenton system with initially adding $20 \mathrm{mg} / \mathrm{L}$ of $\mathrm{Fe}^{2+}$ and $200 \mathrm{mg} / \mathrm{L}$ of $\mathrm{H}_{2} \mathrm{O}_{2}$ at $\mathrm{pH}_{0}$ 3.0. It was found that PNP was destructed quickly within 5 min and exhibited faster decay of PNP and COD than the present combined process within $20 \mathrm{~min}$. However, its final COD removal efficiency was outperformed by the present combined process at $30 \mathrm{~min}$ and was slightly surpassed by the latter (Babuponnusami and Muthukumar, 2014).

The variation of $\mathrm{H}_{2} \mathrm{O}_{2}$ concentration is shown in Figure 5C. It was observed that when applying potential at the iron cathode, the $\mathrm{H}_{2} \mathrm{O}_{2}$ concentration increased initially within $15 \mathrm{~min}$ and then decreased afterwards in the late reaction stage. As compared with the WE Fenton reaction system, the $\mathrm{H}_{2} \mathrm{O}_{2}$ concentration was higher, which was probably due to the smaller release of iron ions from the iron 

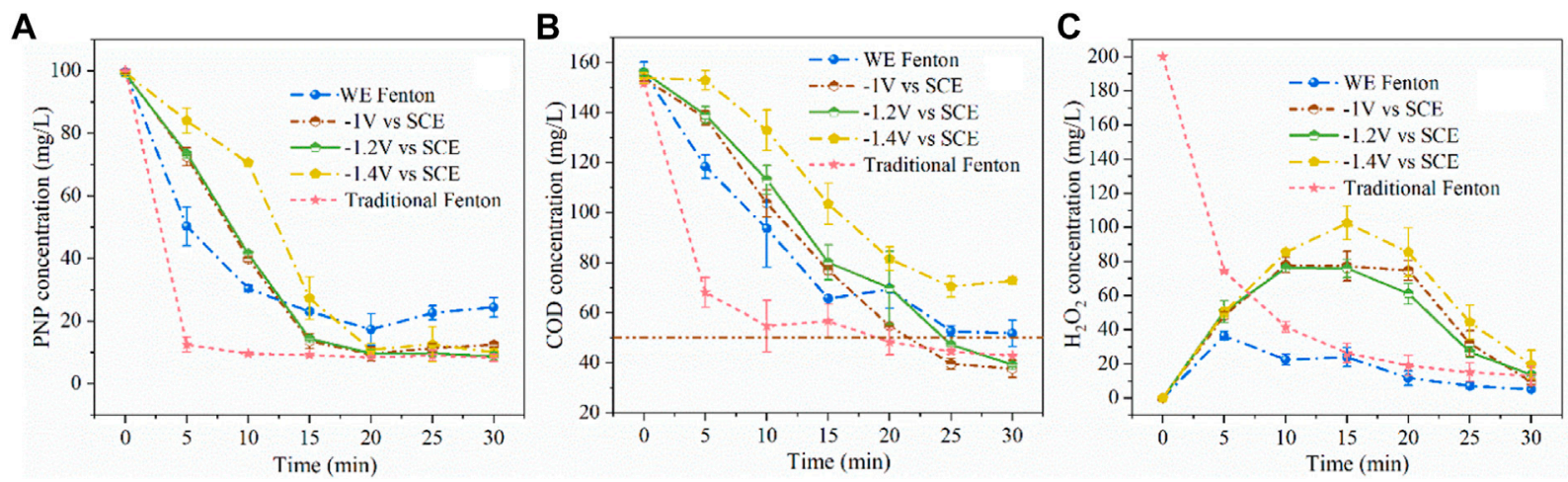

FIGURE 5 | Concentration variations of PNP (A), $\mathrm{COD}(\mathbf{B})$, and $\mathrm{H}_{2} \mathrm{O}_{2}(\mathbf{C})$ during the degradation under different conditions $\left(\mathrm{PNP}=100 \mathrm{mg} / \mathrm{L}, \mathrm{Na}_{2} \mathrm{SO} \mathrm{O}_{4}=3 \mathrm{~g} / \mathrm{L}, \mathrm{pH}\right.$ $=3.0)$.

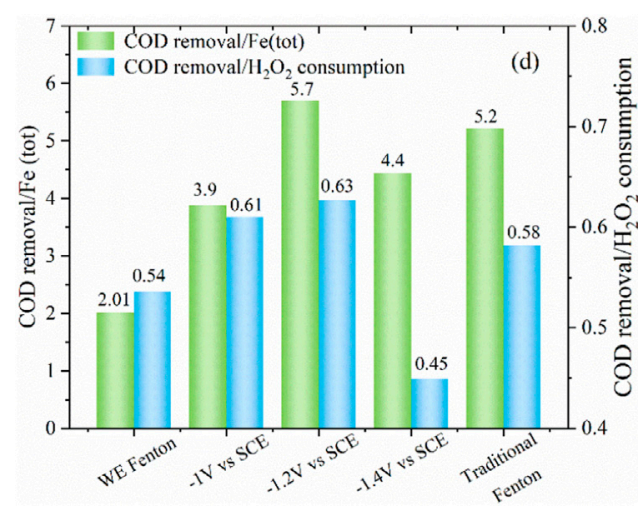

FIGURE 6 | The ratio of COD removal to $\mathrm{Fe}$ (tot) concentration and $\mathrm{H}_{2} \mathrm{O}_{2}$ consumption under different conditions (PNP $=100 \mathrm{mg} / \mathrm{L}, \mathrm{Na}_{2} \mathrm{SO}_{4}=3 \mathrm{~g} / \mathrm{L}$ ).

cathode. As the applied cathodic potential decreased from -1.0 to $-1.4 \mathrm{~V} / \mathrm{SCE}$, the remaining concentration of $\mathrm{H}_{2} \mathrm{O}_{2}$ was slightly higher over the whole reaction period, which was also associated with the production of iron ions. In the traditional Fenton system, the concentration of $\mathrm{H}_{2} \mathrm{O}_{2}$ significantly decreased from 200 to $126 \mathrm{mg} / \mathrm{L}$ within $5 \mathrm{~min}$, which corresponded to the quick reaction between $\mathrm{Fe}^{2+}$ and $\mathrm{H}_{2} \mathrm{O}_{2}$, and the remaining $\mathrm{H}_{2} \mathrm{O}_{2}$ concentration at 30 min was $13 \mathrm{mg} / \mathrm{L}$. From Figure 6, it could be clearly observed that as the cathodic potential decreased from -1.0 to $-1.2 \mathrm{~V} / \mathrm{SCE}$, the ratio of $\mathrm{COD}$ removal to produced $\mathrm{Fe}$ (tot) and $\mathrm{H}_{2} \mathrm{O}_{2}$ consumption was increased from 3.9 to 5.7 and 0.61 to 0.63 , while the value significantly decreased to 4.4 and 0.45 at a higher cathode potential of $1.4 \mathrm{~V} / \mathrm{SCE}$. These results demonstrated that $-1.2 \mathrm{~V} / \mathrm{SCE}$ was the optimal cathodic potential with suitable Fe (tot) production for the electroFenton reaction, which exhibited slightly higher COD removal/Fe (tot) and COD removal/ $\mathrm{H}_{2} \mathrm{O}_{2}$ consumption for the traditional Fenton reaction system. In the WE Fenton process, the much lower value, i.e., 2 for COD removal/Fe (tot) and 0.54 for $\mathrm{COD}$ removal $/ \mathrm{H}_{2} \mathrm{O}_{2}$ consumption, was obtained, respectively.

\section{The Divided Electrolysis Cell and ICEF Combined System}

According to the aforementioned experimental results, the optimal current density for solution $\mathrm{pH}$ regulation and cathodic potential for the ICEF reaction have been obtained. The results of PNP and COD concentration time are shown in Figure 7A. It was found that the PNP concentration of the anodic effluent slightly decreased from 100 to $91 \mathrm{mg} / \mathrm{L}$ while the COD removal efficiency was only $5 \%$, owing to the oxidation at the BDD anode. During the combined process, the removal efficiency of PNP and COD attained 93 and $72 \%$ within $30 \mathrm{~min}$, and the PNP pollutant was further destructed after filtration because of the coagulation of iron ions with the concentration decreased from 6 to $2 \mathrm{mg} / \mathrm{L}$. Figure 7B shows the TOC removal efficiency of traditional Fenton and ICFE systems, the removal efficiency was $42 \%$ within 5 min by traditional Fenton but maintained relatively stable in the remaining time, finally the value reached $48 \%$. This can be explained by the rapid consumption rate of Fenton reagents. However, the TOC removal efficiency achieved $60 \%$ in the combined system, which was much higher than traditional Fenton (Kavitha and Palanivelu, 2004). The high removal efficiency of PNP (98\%), COD (79\%), and TOC (60\%) revealed more efficient degradation of pollutants in the combined system than the traditional Fenton system.

For traditional Fenton, $\mathrm{pH}$ was adjusted to the desired values with $\mathrm{H}_{2} \mathrm{SO}_{4}$ and $\mathrm{NaOH}$ solution while ferrous sulfate was used as the iron ions source (Gao et al., 2020). As shown in Figure 8, the conductivity was increased from 4.35 to $4.68 \mathrm{mS}$ / $\mathrm{cm}$ after acidification during traditional Fenton, and the value continuously enhanced to 4.95 after the Fenton reaction, while the $\mathrm{pH}$ slightly decreased from 3.07 to 2.73 , which can be explained by the large quantity of organic acids production. The $\mathrm{pH}$ of the effluent was neutralized to approximately 9.0 with the conductivity reduced to $4.76 \mathrm{mS} / \mathrm{cm}$, which might be caused by acid-base 

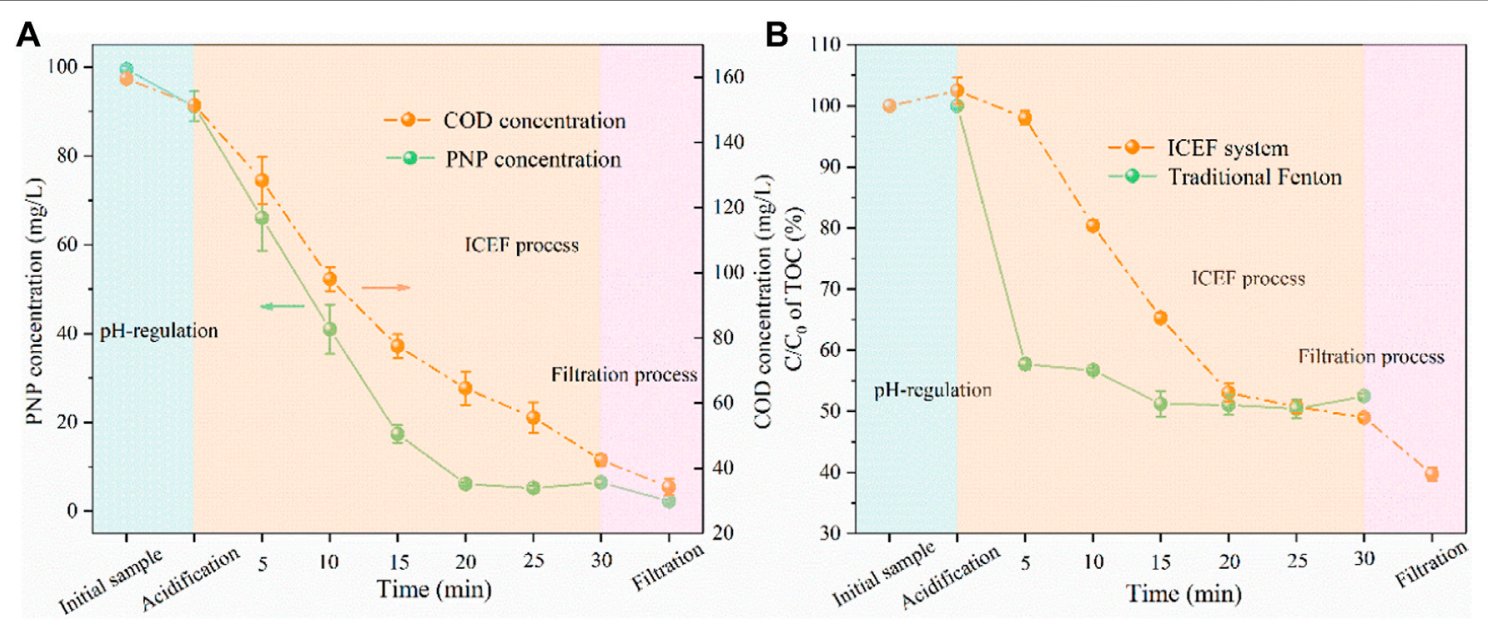

FIGURE 7 | Concentration variations of $\mathrm{PNP}$ and $\mathrm{COD}(\mathbf{A})$ and $\mathrm{TOC}$ concentration reduction $\mathbf{( B )}$ during the EIC-EF system degradation $\left(\mathrm{PNP}=100 \mathrm{mg} / \mathrm{L}, \mathrm{Na}_{2} \mathrm{SO}{ }_{4}\right.$ $\left.=3 \mathrm{~g} / \mathrm{L}, \mathrm{pH}_{\mathrm{O}}=7.0\right)$.

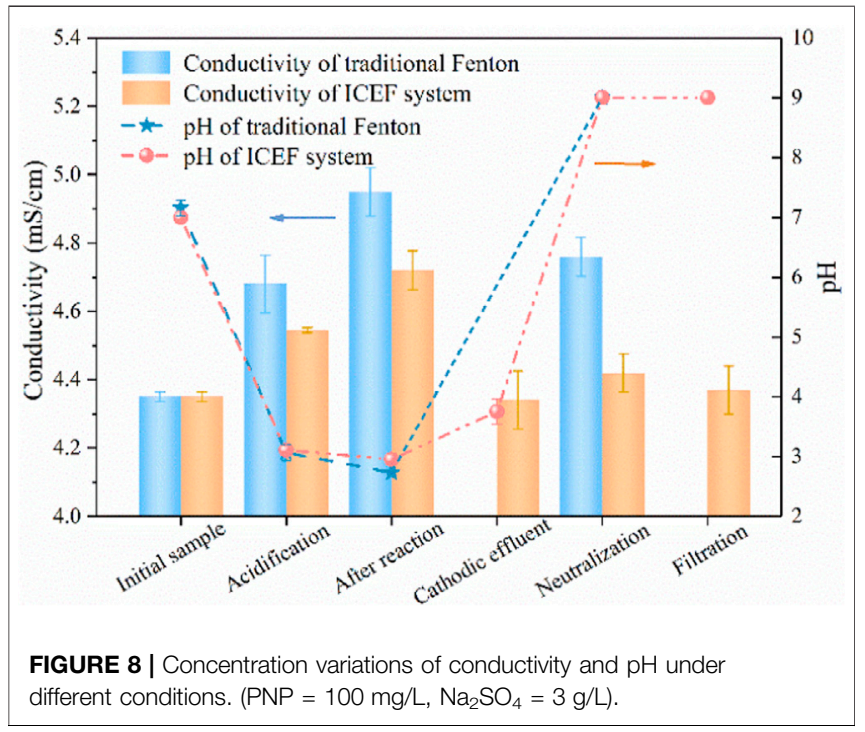

neutralization. As for the present combined process, the conductivity of the anodic effluent increased to $4.55 \mathrm{mS} / \mathrm{cm}$ with the $\mathrm{pH}$ decreasing from 7.0 to 3.1 , the cathodic effluent $\mathrm{pH}$ only slightly increased from 2.95 to 3.75 at the same current density $\left(2 \mathrm{~mA} / \mathrm{cm}^{2}\right)$, owing to the buffering effect of organic acids on $\mathrm{pH}$. During the neutralization process, $\mathrm{pH}$ was further adjusted to neutral ( 9.0) by the $\mathrm{NaOH}$ solution (Chen et al., $2021)$, driving the complete precipitation of $\mathrm{Fe}(\mathrm{OH})_{3}$. In this case, the conductivity further decreased to $4.37 \mathrm{mS} / \mathrm{cm}$. Generally, the salinity of traditional Fenton increased by $9 \%$ compared with the initial solution while the present combined process remained basically unchanged after the reaction, avoiding the obvious increase of water salinity caused by the addition of a large amount of chemical reagents in traditional Fenton.

\section{Mechanism Discussion}

A set of experiments was performed to verify the main mechanism of pollutant degradation. As shown in Figures 9A,B, the PNP removal efficiency was only $9 \%$ without frontend $\mathrm{pH}$ adjustment, owing to basically no $\mathrm{Fe}^{2+}$ production under the neutral solution, indicating that the $\mathrm{pH}$-regulation process is indispensable for the ICEF system. In addition, only 7\% of PNP was oxidized by $\mathrm{H}_{2} \mathrm{O}_{2}$ in solution. In the above two reaction system, COD concentration slightly increased after the reaction, which was possibly subject to formation of some intermediates which interfered with the COD concentration. The direct oxidation of PNP by the DSA anode was also examined without $\mathrm{H}_{2} \mathrm{O}_{2}$ at $\mathrm{pH}_{0}=3.0$, the removal efficiency of PNP and COD concentration were 38 and $13 \%$, respectively. Thus, the direct PNP degradation at the anode was ruled out, indicating that PNP in solution was mainly oxidized by $\bullet \mathrm{OH}$ produced by the Fenton reaction.

To further investigate the effect of cathode potential on iron ion concentration, we conducted the following experiments. As shown in Figure 10A, at the cathode potential of $-1.2 \mathrm{~V} / \mathrm{SCE}$ without adding $\mathrm{H}_{2} \mathrm{O}_{2}$, the produced $\mathrm{Fe}$ (tot) concentration was $4 \mathrm{mg} / \mathrm{L}$, which reduced by $80 \%$ compared with no electricity as shown in Figure $3(20 \mathrm{mg} / \mathrm{L})$. And in the case of adding $200 \mathrm{mg} / \mathrm{L}$ of $\mathrm{H}_{2} \mathrm{O}_{2}$ and applying the cathode potential of $-1.2 \mathrm{~V} / \mathrm{SCE}$, the $\mathrm{Fe}$ (tot) concentration increased to $17 \mathrm{mg} / \mathrm{L}$. There are two reasons for this phenomenon, one is that the iron plate would react with $\mathrm{H}_{2} \mathrm{O}_{2}$ in the presence of $\mathrm{H}^{+}$through Eq. 10 (Pan et al., 2019); the other is that the presence of $\mathrm{H}_{2} \mathrm{O}_{2}$ promoted the conversion of $\mathrm{Fe}^{2+}$ to $\mathrm{Fe}^{3+}$ and the generated $\mathrm{Fe}^{3+}$ may further react with the iron plate to produce $\mathrm{Fe}^{2+}$ through Eq. 11. As shown in Figure 10B, $30 \mathrm{mg} / \mathrm{L}$ of $\mathrm{Fe}^{3+}$ was also added into the solution at the cathodic potential of $-1.2 \mathrm{~V} / \mathrm{SCE}$ without $\mathrm{H}_{2} \mathrm{O}_{2}$, the $\mathrm{Fe}$ (tot) concentration slightly increased to $35 \mathrm{mg} / \mathrm{L}$ within $30 \mathrm{~min}$ and $\mathrm{Fe}^{3+}$ concentration reduced to $26 \mathrm{mg} / \mathrm{L}$. The results demonstrated that the reaction between $\mathrm{Fe}^{3+}$ and $\mathrm{Fe}^{0}$ contributed marginally to 

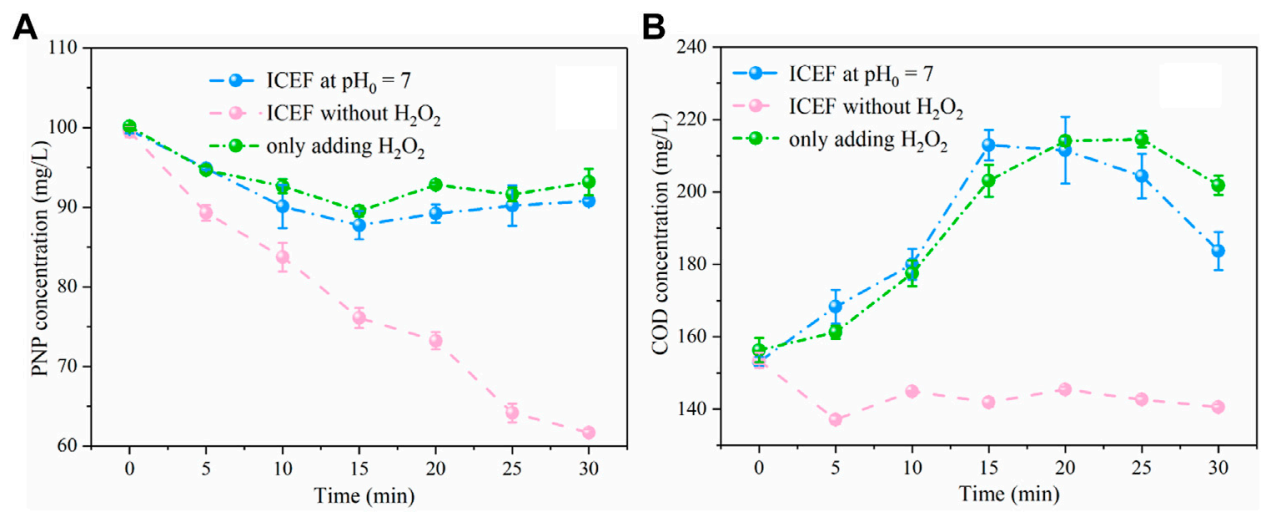

FIGURE 9 | Concentration variations of PNP (A) and COD (B) under different conditions $\left(\mathrm{PNP}=100 \mathrm{mg} / \mathrm{L}, \mathrm{Na}_{2} \mathrm{SO} \mathrm{H}_{4}=3 \mathrm{~g} / \mathrm{L}\right)$.
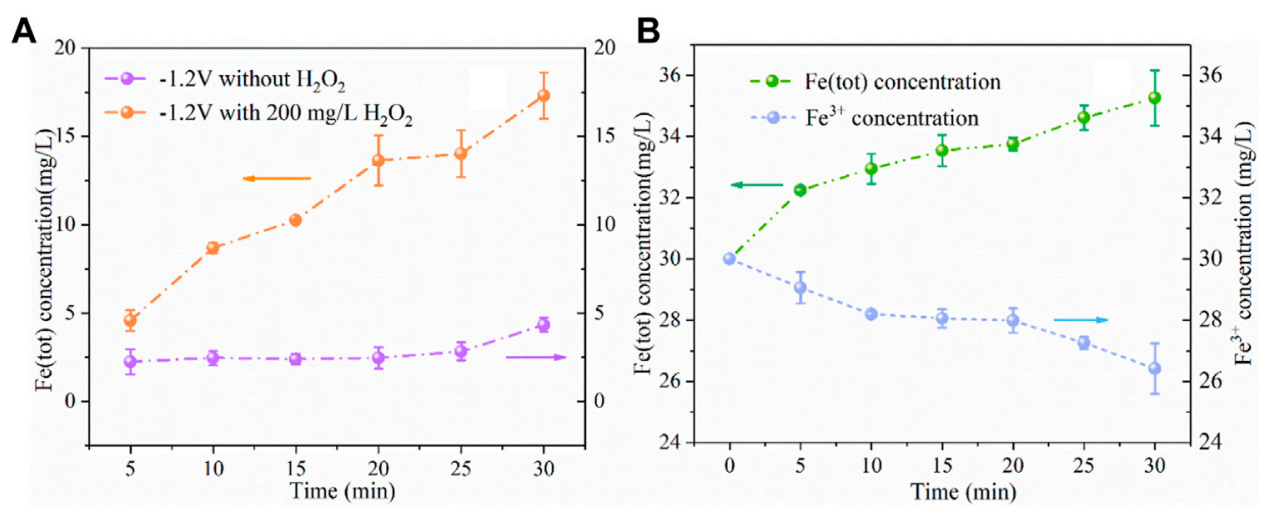

FIGURE 10 | Concentration variations of $\mathrm{Fe}(\mathrm{tot})$ and $\mathrm{Fe}^{2+} \mathbf{( A )}$ and $\mathrm{Fe}$ (tot) and $\mathrm{Fe}^{3+}$

(B) under different conditions (PNP $=100 \mathrm{mg} / \mathrm{L}, \mathrm{Na}_{2} \mathrm{SO}_{4}=3 \mathrm{~g} / \mathrm{L}, \mathrm{pH}_{0}=3.0$ ).
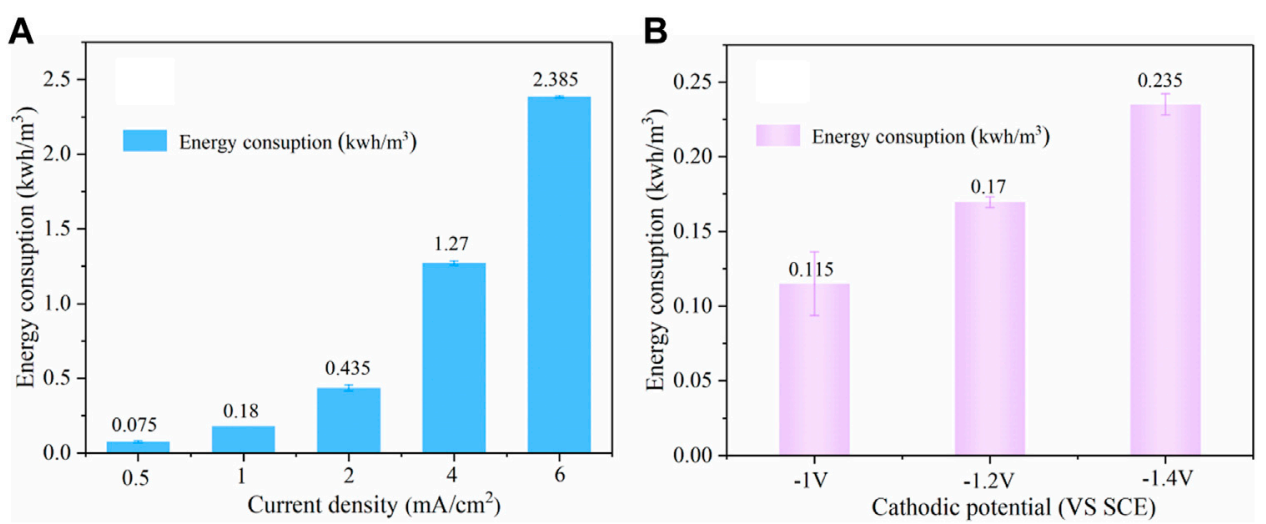

FIGURE 11 | Effect of different current densities (A) and cathodic potential (B) on energy consumption $\left(\mathrm{PNP}=100 \mathrm{mg} / \mathrm{L}, \mathrm{Na}_{2} \mathrm{SO} \mathrm{O}_{4}=3 \mathrm{~g} / \mathrm{L}, \mathrm{pH}=7.0\right)$.

the release of iron ions during the ICEF process, while the direct oxidation of $\mathrm{Fe}^{0}$ by $\mathrm{H}_{2} \mathrm{O}_{2}$ probably dominated the release of iron ions from the iron plate. As a result, in the WE Fenton system, $\mathrm{H}_{2} \mathrm{O}_{2}$ was not only consumed for the Fenton reaction but also for the release of $\mathrm{Fe}^{2+}$ by the reaction with the iron plate. Thus, a part of $\mathrm{H}_{2} \mathrm{O}_{2}$ cannot be utilized for $\bullet \mathrm{OH}$ production via the Fenton reaction, leading to the inferior degradation efficiency of PNP.

$$
\begin{aligned}
\mathrm{Fe}+\mathrm{H}_{2} \mathrm{O}_{2}+2 \mathrm{H}^{+} & \rightarrow \mathrm{Fe}^{2+}+2 \mathrm{H}_{2} \mathrm{O} \\
\mathrm{Fe}^{3+}+\mathrm{Fe} & \rightarrow \mathrm{Fe}^{2+}
\end{aligned}
$$




\section{Environmental Implication}

In the present combined system, the cost for electricity played an important role in the overall operating cost of the process. Apparently, the overall energy consumption is the sum of the $\mathrm{pH}$ adjustment unit and Fenton reaction process, the power consumption of per ton of wastewater was calculated based on Eq. 12 (Wang and Chu, 2011).

$$
\mathrm{E}=\frac{\mathrm{UIT}}{\mathrm{V}} \times 10^{-3}
$$

where $\mathrm{E}$ is the energy consumption, $\mathrm{U}$ is the voltage measured during the reaction (V), I is the applied current (A), $t$ is the electrolysis time $(\mathrm{h})$, and $\mathrm{V}$ is the volume of reaction solution $\left(\mathrm{m}^{3}\right)$.

As shown in Figure 11A, during the $\mathrm{pH}$-regulation process, current density had a significant impact on energy consumption, the value increased from 0.075 to $2.385 \mathrm{kWh} / \mathrm{m}^{3}$ as the current density increased from 0.5 to $6 \mathrm{~mA} / \mathrm{cm}^{2}$. In the present combined system, a $\mathrm{pH}$ of 3.0-3.2 was automatically attained by electrolysis with the energy consumption of $0.435 \mathrm{kWh} / \mathrm{m}^{3}$. Figure 11B shows that the energy consumption was increased from 0.115 to $0.235 \mathrm{kWh} / \mathrm{m}^{3}$ with the cathodic potential decreasing from -1.0 to $-1.4 \mathrm{~V} / \mathrm{SCE}$. We can infer that the $\mathrm{pH}$-regulation took up most energy consumption (72\%) in our system, and the whole system power consumption of per ton of wastewater was $0.605 \mathrm{kWh} / \mathrm{m}^{3}$, which translates into a cost of $\$ 0.04 / \mathrm{m}^{3}$ based on the average US industrial electricity rate $(\$ 0.0653 / \mathrm{kWh})$. Iron sheet is very cheap and highly reusable (\$1.4), which can counteract the cost. The cost of $\mathrm{H}_{2} \mathrm{O}_{2}$ was $\$ 0.16$ with $0.6 \mathrm{~L}$ of consumption per ton of water, while the unit price of $\mathrm{H}_{2} \mathrm{O}_{2}$ was $\$ 0.27 / \mathrm{L}$. Furthermore, in situ electrochemical synthesis of highly concentrated $\mathrm{H}_{2} \mathrm{O}_{2}$ (Yamanaka et al., 2003; Chen et al., 2017) could be used as a replacement for externally supplied $\mathrm{H}_{2} \mathrm{O}_{2}$ in the future, eliminating the chemical cost.

The specific energy consumption was calculated in terms of the removal of $1 \mathrm{~kg}$ of COD from PNP wastewater by the Fenton process (kWh/kg COD) using Eq. 13, where U, I, and t are the average voltage $(\mathrm{V})$, applied current $(\mathrm{A})$, and electrolysis time (s), respectively (Kurt et al., 2007; Zhao et al., 2016).

$$
\mathrm{SEC}=\frac{\mathrm{U} \times \mathrm{I} \times \mathrm{T}}{\left(\mathrm{COD}_{0} \times \mathrm{V}_{0}-\mathrm{COD}_{\mathrm{t}} \times \mathrm{V}_{\mathrm{t}}\right) \times 3.6}
$$

After $\mathrm{pH}$ adjustment and the 30-min ICEF process, the PNP mineralization shows an SEC value of $4.92 \mathrm{kWh} / \mathrm{kg}$ COD, the results in this study demonstrated that the ICEF system was environmentally friendly, efficient, and inexpensive in comparison. It was proven that the operation of the system greatly enhanced the treatment of PNP wastewater. Compared to traditional Fenton and other electro-Fenton systems, the ICEF system has its own merits. Firstly, the $\mathrm{pH}$-regulation divided electrolysis cell with the PTFE membrane as the separating material was simple and convenient compared to others, an acidic $\mathrm{pH}$ of 3.0-3.2 was automatically attained at a steady state within $1 \mathrm{~min}$, which is suitable for most Fentonlike reactions (Babuponnusami and Muthukumar, 2014). In contrast, $\sim 60$ min was required in the divided electrolysis cell using an ion exchange membrane as the separating material (Liu et al., 2007). Secondly, the cathode potential applied on the iron plate can decrease amounts of iron irons released under acid solution and precisely control the Fe (tot) production, avoiding the addition of iron salt and increase of water salinity. All these advantages together suggest that the ICEF system has potential for cost-effective and efficient degradation of recalcitrant organic pollutants. Future work should also focus on improving the efficiency of cathode reduction of ferric iron and improving the efficiency of $\mathrm{H}_{2} \mathrm{O}_{2}$ utilization.

\section{CONCLUSION}

In this study, a novel eco-friendly iron cathode electrochemical Fenton (ICEF) system coupled with a $\mathrm{pH}$ regulation divided electrolysis cell was developed for PNP degradation. In such a system, $100 \mathrm{mg} / \mathrm{L}$ of PNP was not only effectively degraded within $30 \mathrm{~min}$ (97\%), but also efficiently mineralized with a COD and TOC removal efficiency of 79 and $60 \%$, respectively. The optimal cathode potential exhibited strong inhibition on Fe (tot) production with the concentration of Fe (tot) significantly decreasing from 52 to $21 \mathrm{mg} / \mathrm{L}$, minimizing the ferric sludge generation. And the conductivity increased slightly from 4.35 to $4.37 \mathrm{mS} / \mathrm{cm}$, indicating that the present combined process negligibly affected the salt content of the wastewater. Notably, the system was inexpensive with an energy consumption of only $4.92 \mathrm{kWh} / \mathrm{kg}$ COD. In general, this study demonstrated that the present combined system is an effective and environmentally friendly technology for wastewater treatment.

\section{DATA AVAILABILITY STATEMENT}

The original contributions presented in the study are included in the article/Supplementary Material, further inquiries can be directed to the corresponding author.

\section{AUTHOR CONTRIBUTIONS}

XW: Conceptualization, Investigation, Writing, and Original Draft preparation. JZ: Investigation and Formal analysis. CS: Formal analysis and Investigation. XS: Validation, Formal analysis, Investigation, and Supervision. PD: Software and Methodology. 


\section{REFERENCES}

Andreozzi, R., Caprio, V., Insola, A., and Marotta, R. (1999). Advanced Oxidation Processes (AOP) for Water Purification and Recovery. Catal. Today. 53, 51-59. doi:10.1016/s0920-5861(99)00102-9

Babuponnusami, A., and Muthukumar, K. (2014). A Review on Fenton and Improvements to the Fenton Process for Wastewater Treatment. J. Environ. Chem. Eng. 2, 557-572. doi:10.1016/j.jece.2013.10.011

Bello, M. M., Abdul Raman, A. A., and Asghar, A. (2019). A Review on Approaches for Addressing the Limitations of Fenton Oxidation for Recalcitrant Wastewater Treatment. Process Saf. Environ. Prot. 126, 119-140. doi:10.1016/j.psep.2019.03.028

Brillas, E., Sirés, I., and Oturan, M. A. (2009). Electro-Fenton Process and Related Electrochemical Technologies Based on Fenton's Reaction Chemistry. Chem. Rev. 109, 6570-6631. doi:10.1021/cr900136g

Cai, Q. Q., Lee, B. C. Y., Ong, S. L., and Hu, J. Y. (2021). Fluidized-bed Fenton Technologies for Recalcitrant Industrial Wastewater Treatment-Recent Advances, Challenges and Perspective. Water Res. 190, 116692. doi:10.1016/j.watres.2020.116692

Chen, L., Alshawabkeh, A. N., Hojabri, S., Sun, M., Xu, G., and Li, J. (2021). A Robust Flow-Through Platform for Organic Contaminant Removal. Cel Rep. Phys. Sci. 2, 100296. doi:10.1016/j.xcrp.2020.100296

Chen, Z., Chen, S., Siahrostami, S., Chakthranont, P., Hahn, C., Nordlund, D., et al. (2017). Development of a Reactor with Carbon Catalysts for Modular-Scale, Low-Cost Electrochemical Generation of $\mathrm{H}_{2} \mathrm{O}_{2}$. React. Chem. Eng. 2, 239-245. doi:10.1039/c6re00195e

Davarnejad, R., and Azizi, J. (2016). Alcoholic Wastewater Treatment Using Electro-Fenton Technique Modified by $\mathrm{Fe}_{2} \mathrm{O}_{3}$ Nanoparticles. J. Environ. Chem. Eng. 4, 2342-2349. doi:10.1016/j.jece.2016.04.009

Fang, F., Yang, M.-M., Wang, H., Yan, P., Chen, Y.-P., and Guo, J.-S. (2018). Effect of High Salinity in Wastewater on Surface Properties of Anammox Granular Sludge. Chemosphere. 210, 366-375. doi:10.1016/j.chemosphere.2018.07.038

Ganiyu, S. O., Zhou, M., and Martínez-Huitle, C. A. (2018). Heterogeneous Electro-Fenton and Photoelectro-Fenton Processes: a Critical Review of Fundamental Principles and Application for Water/Wastewater Treatment. Appl. Catal. B: Environ. 235, 103-129. doi:10.1016/j.apcatb.2018.04.044

Gao, J., Jiang, B., Ni, C., Qi, Y., and Bi, X. (2020). Enhanced Reduction of Nitrate by Noble Metal-Free Electrocatalysis on P Doped Three-Dimensional Co3O4 Cathode: Mechanism Exploration from Both Experimental and DFT Studies. Chem. Eng. J. 382, 123034. doi:10.1016/j.cej.2019.123034

Gao, Y., Zhu, Y., Lyu, L., Zeng, Q., Xing, X., and Hu, C. (2018). Electronic Structure Modulation of Graphitic Carbon Nitride by Oxygen Doping for Enhanced Catalytic Degradation of Organic Pollutants Through Peroxymonosulfate Activation. Environ. Sci. Technol. 52, 14371-14380. doi:10.1021/acs.est.8b05246

Görmez, F., Görmez, Ö., Gözmen, B., and Kalderis, D. (2019). Degradation of Chloramphenicol and Metronidazole by Electro-Fenton Process Using Graphene Oxide- $\mathrm{Fe}_{3} \mathrm{O}_{4}$ as Heterogeneous Catalyst. J. Environ. Chem. Eng. 7, 102990. doi:10.1016/j.jece.2019.102990

Hassani, A., Karaca, M., Karaca, S., Khataee, A., Açışlı, Ö., and Yılmaz, B. (2018). Preparation of Magnetite Nanoparticles by High-Energy Planetary ball Mill and its Application for Ciprofloxacin Degradation through Heterogeneous Fenton Process. J. Environ. Manage. 211, 53-62. doi:10.1016/j.jenvman.2018.01.014

He, J., Yang, X., Men, B., and Wang, D. (2016). Interfacial Mechanisms of Heterogeneous Fenton Reactions Catalyzed by Iron-Based Materials: A Review. J. Environ. Sci. 39, 97-109. doi:10.1016/j.jes.2015.12.003

$\mathrm{Hu}$, J., Wang, S., Yu, J., Nie, W., Sun, J., and Wang, S. (2021). Duet $\mathrm{Fe}_{3} \mathrm{C}$ and FeNx Sites for $\mathrm{H}_{2} \mathrm{O}_{2}$ Generation and Activation Toward Enhanced Electro-Fenton Performance in Wastewater Treatment. Environ. Sci. Technol. 55, 1260-1269. doi:10.1021/acs.est.0c06825

Kavitha, V., and Palanivelu, K. (2004). The Role of Ferrous Ion in Fenton and Photo-Fenton Processes for the Degradation of Phenol. Chemosphere. 55, 1235-1243. doi:10.1016/j.chemosphere.2003.12.022

Kurt, U., Apaydin, O., and Gonullu, M. T. (2007). Reduction of COD in Wastewater from an Organized Tannery Industrial Region by Electro-Fenton Process. J. Hazard. Mater. 143, 33-40. doi:10.1016/j.jhazmat.2006.08.065

Li, Q., Wang, M., Feng, J., Zhang, W., Wang, Y., Gu, Y., et al. (2013). Treatment of High-Salinity Chemical Wastewater by Indigenous Bacteria - Bioaugmented
Contact Oxidation. Bioresour. Technology. 144, 380-386. doi:10.1016/ j.biortech.2013.07.004

Liu, H., Wang, C., Xiangzhong, X., Xuan, X., Jiang, C., and Cui, H. n. (2007). A Novel Electro-Fenton Process for Water Treatment: Reaction-Controlled $\mathrm{pH}$ Adjustment and Performance Assessment. Environ. Sci. Technol. 41, 2937-2942. doi:10.1021/es0622195

Moreira, F. C., Boaventura, R. A. R., Brillas, E., and Vilar, V. J. P. (2017). Electrochemical Advanced Oxidation Processes: a Review on Their Application to Synthetic and Real Wastewaters. Appl. Catal. B: Environ. 202, 217-261. doi:10.1016/j.apcatb.2016.08.037

Nakatsuji, Y., Salehi, Z., and Kawase, Y. (2015). Mechanisms for Removal of P-Nitrophenol from Aqueous Solution Using Zero-Valent Iron. J. Environ. Manage. 152, 183-191. doi:10.1016/j.jenvman.2015.01.012

Neyens, E., and Baeyens, J. (2003). A Review of Classic Fenton's Peroxidation as an Advanced Oxidation Technique. J. Hazard. Mater. 98, 33-50. doi:10.1016/ s0304-3894(02)00282-0

Oturan, M. A., and Aaron, J.-J. (2014). Advanced Oxidation Processes in Water/ Wastewater Treatment: Principles and Applications. A Review. Crit. Rev. Environ. Sci. Technology. 44, 2577-2641. doi:10.1080/10643389.2013.829765

Oturan, M. A., Peiroten, J., Chartrin, P., and Acher, A. J. (2000). Complete Destruction of P-Nitrophenol in Aqueous Medium by Electro-Fenton Method. Environ. Sci. Technol. 34, 3474-3479. doi:10.1021/es990901b

Pan, Y., Zhou, M., Cai, J., Tian, Y., and Zhang, Y. (2019). Mechanism Study of Nitrilotriacetic Acid-Modified Premagnetized $\mathrm{Fe} 0 / \mathrm{H}_{2} \mathrm{O}_{2}$ for Removing Sulfamethazine. Chem. Eng. J. 374, 1180-1190. doi:10.1016/j.cej.2019.06.005

Qiang, Z., Chang, J.-H., and Huang, C.-P. (2003). Electrochemical Regeneration of Fe2+ in Fenton Oxidation Processes. Water Res. 37, 1308-1319. doi:10.1016/ s0043-1354(02)00461-x

Wang, X. G., Lin, B., Tang, Y. B., and Chen, H. F. (2014). Effects of High Salinity on the Removal of Pollutants in Wastewater by Aerobic Granular Sludge. Amr. 955-959, 339-342. doi:10.4028/www.scientific.net/amr.955959.339

Wang, Y. R., and Chu, W. (2011). Degradation of 2,4,5-Trichlorophenoxyacetic Acid by a Novel Electro-Fe(II)/Oxone Process Using Iron Sheet as the Sacrificial Anode. Water Res. 45, 3883-3889. doi:10.1016/j.watres.2011.04.034

Xin, S., Nin, C., Gong, Y., Ma, J., Bi, X., and Jiang, B. (2018). A Full-Wave Rectified Alternating Current Wireless Electrocoagulation Strategy for the Oxidative Remediation of As(III) in Simulated Anoxic Groundwater. Chem. Eng. J. 351, 1047-1055. doi:10.1016/j.cej.2018.06.178

Yamanaka, I., Onizawa, T., Takenaka, S., and Otsuka, K. (2003). Direct and Continuous Production of Hydrogen Peroxide with 93 \% Selectivity Using a Fuel-Cell System. Angew. Chem. Int. Ed. Engl. 42, 3653-3655. doi:10.1002/ anie.200351343

Yuan, S., Tian, M., Cui, Y., Lin, L., and Lu, X. (2006). Treatment of Nitrophenols by Cathode Reduction and Electro-Fenton Methods. J. Hazard. Mater. 137, 573-580. doi:10.1016/j.jhazmat.2006.02.069

Zhao, H., Qian, L., Guan, X., Wu, D., and Zhao, G. (2016). Continuous Bulk FeCuC Aerogel with Ultradispersed Metal Nanoparticles: An Efficient 3D Heterogeneous Electro-Fenton Cathode over a Wide Range of pH 3-9. Environ. Sci. Technol. 50, 5225-5233. doi:10.1021/acs.est.6b00265

Conflict of Interest: Authors XW, JZ, CS, XS and HD were employed by company Shengli Oilfield Testing and Evaluation Research Co., Ltd., SINOPEC.

Publisher's Note: All claims expressed in this article are solely those of the authors and do not necessarily represent those of their affiliated organizations, or those of the publisher, the editors and the reviewers. Any product that may be evaluated in this article, or claim that may be made by its manufacturer, is not guaranteed or endorsed by the publisher.

Copyright (c) 2022 Wang, Zhao, Song, Shi and Du. This is an open-access article distributed under the terms of the Creative Commons Attribution License (CC BY). The use, distribution or reproduction in other forums is permitted, provided the original author(s) and the copyright owner(s) are credited and that the original publication in this journal is cited, in accordance with accepted academic practice. No use, distribution or reproduction is permitted which does not comply with these terms. 